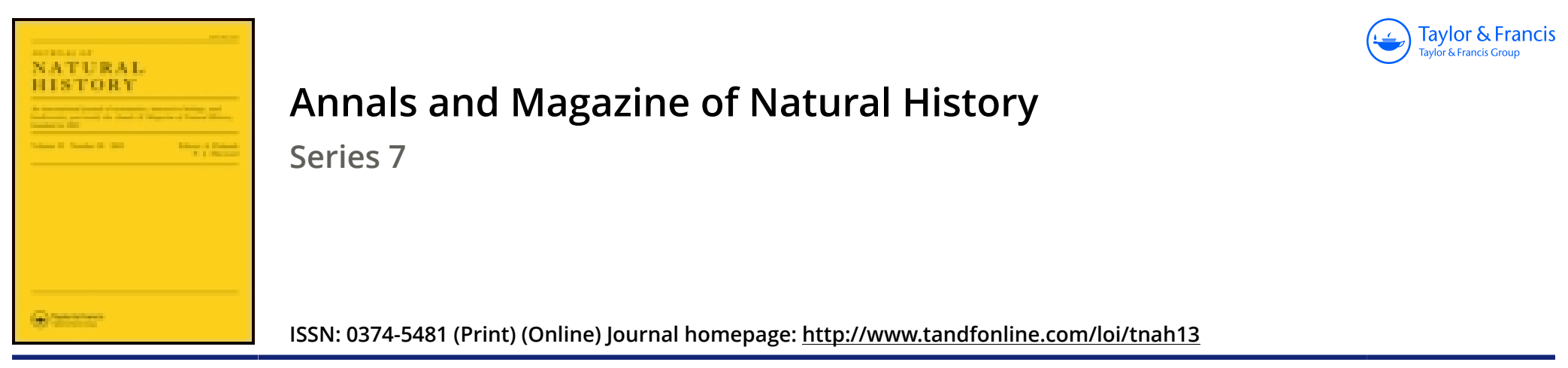

\title{
XII.-On two new squirrels of the Funisciurus pyrrhopus group
}

\section{Oldfield Thomas}

To cite this article: Oldfield Thomas (1903) XII.-On two new squirrels of the Funisciurus pyrrhopus group , Annals and Magazine of Natural History, 11:61, 79-81, DOI: 10.1080/00222930308678728

To link to this article: http://dx.doi.org/10.1080/00222930308678728

册 Published online: 28 Sep 2009.

Submit your article to this journal $₫$

WII Article views: 1

Q View related articles 5 
breadth; occipital shelf strongly narrowing posteriorly; zygomata practically without projecting antero-external shoulders; palatal foramina large and widely open; palatal bridge quite narrow; bullæ of medium size. Incisors of a very simple pattern, the enamel not penetrating into the tooth at all, but merely following its anterior outline ; inner segment of each tooth two thirds the breadth of the outer. Molars as in truo Lepus, not as in Oryctolagus crassicaudatus. Dimensions of the type (measured in the flesh) :-

Head and body 398 millim.; tail 76, with hair 100 ; hind foot 107; ear 107 .

Skull: greatest length 80.5 ; basilar length 63 ; zygomatic breadth 37 ; nasals 33 (diagonally) $\times 16$; interorbital breadth 14 ; intertemporal breadth 13.5 ; length of palatal foramina 20 ; breadth of palatal bridge 5.2 ; antero-posterior diameter of bullæ $12 \cdot 3$.

Hab. Deelfontein, Cape Colony.

Type. Female. Original number 284. Collected 24th May, 1902, by Trooper C. H. B. Grant and presented by Col. A. T. Sloggett, R.A.M.C.

To the three types of hare found in South Africa, $L$. capensis, L. saxatilis, and O. crassicaudatus, all of them obtained at Deelfontein, the present adds a fourth very distinct one, without near allies anywhere.

Although with a general resemblance to $O$. crassicaudatus, with which it shares the characteristic form of the tail, it may be distinguished externally by its brownish-drab instead of rufous tail, the absence of rufous suffusion in its body-colour, the presence of a narrow line of black round the tips of the ears, and the striking coloration of the under surface. Finally, the skull shows that it has no real relationship to that animal, but is more nearly allied to $L$. capensis.

Col. Sloggett and Mr. Grant are to be congratulated on the discovery of this very remarkable hare, the most distinct that has been described for a long time.

XII.-On Two new Squirrels of the Funiscinus pyrrhopus Group. By OLDField Thomas.

Funisciurus mandingo, sp. n.

A small pale form allied to $F$. leucostigma, with the red of the flanks and limbs almost obsolete.

General colour above coarsely grizzled pale olivaceous, much paler than in the allied species. Light stripes present, 
but far less conspicuous than usual, dull yellowish ; the darker region below them hardly perceptible, not contrasting with the colour of the flanks. Under surface dull creamy yellow, not sharply defined, the bases of the hairs slaty grey. Muzzle yellowish, a narrow dark line on its centre above. Cheeks with the lineated arrangement found in this group wherever the strong red of the sides does not overpower it; lines of the upper and lower eyelids yellow, separated by a darker spot in front of and darker line behind the eye. Ears short, dull greyish, the lower part of their backs and a spot behind them dull white. Cheeks below ears, sides of neck, shoulders, flanks, and hips dull fulvous, very different to the conspicuous reddish of the allied forms. Front of forearms and upper surface of hands and feet dull grizzled yellowish. Hairs of tail above annulated black and white, with white tips; below dull ochraceous basally, black subterminally, and white terminally.

Skull not preserved.

Dimensions of the type (measured in skin) :-

Head and body 190 millim.; tail 158 ; hind foot (s. u.) 41. Hab. Nianimaru, Gambia.

Type. Male. B.M. no. 99. 12. 6. 2. Original number 106. Collected 15th January, 1899, and presented by J. S. Budgett, Esq.

This squirrel is most nearly allied to $F$. leucostigma, of which it forms a pale Gambian representative.

\section{Funisciurus raptorum, sp. $\mathrm{n}$.}

A dark form of the group, with the red on sides and flanks almost obsolete.

General colour above dark blackish olivaceous, darker than in ordinary specimens of $F$. leucostigma. Light lines narrow, conspicuous, white instead of the usual yellow; a well-defined dark band below them. Flanks dull brownish, scarcely rufous. Under surface dull cream-white throughout, the hairs white to their roots. Crown blackish, darker than the back. Sides of face lineated, very much as in $F$. mystax, de Wint.; a light orange line running along above the eye, another below it, these being separated by a dark line through it. Cheeks, like flanks, brown, scarcely rufous; shoulders and hips dull rufous brown, which colour is continued down to the wrists and ankles; hands and feet greyish brown, with a tinge of yellowish. Tail-hairs above blackish at base, then dull yellowish, with a black subterminal and white terminal band; centre of under surface dull fulvous. 
Molars of the ordinary character, not as in $F$. mystax*. Dimensions of the type (measured in skin):-

Head and body 190 millim.; tail 155; hind foot (s. u.) 41.

Skull : greatest length 46 ; basilar length 34 ; length of upper molar series $\left(m p^{4}\right.$ and 3 molars) $7 \cdot 5$.

Hab. Forçados, Lower Nigeria.

Type. Immature male. B.M. no. 2. 11. 2. 15. Original number 10. Collected 31st December, 1901, by Di. W. J. Ansorge.

This species differs from $F$. pyrrhopus and $F$. leucostigmr by the almost complete suppression of the red of the cheeks, limbs, and Hanks, and the whiteness of its light dorsal lines, from $F$. mystax by these lines being much more conspicuous, and by its white under surface, and from $F$. mandingo by its generally darker colour.

\section{XIII.-On some Genera and Species of South-American Aviculariidæe. By R. I. Pocock.}

\section{Genus Avicularia, Lam.}

Avicularia minatrix, sp. n.

9.- Colour. Carapace and upperside of appendages covered with olive-grey hairs, showing a delicate tinge of pink; a conspicuous fringe of pink hairs at the extremity of the tibial and protarsal segments of the legs on the dorsal side, a similar but shorter and less noticeable fringe on the extremity of the patella; hairy fringe at the extremity of the tarsus much less noticeably red than that of the protarsus; sternum, coxæ, and underside of abdomen sooty black, upperside of abdomen vividly black and red; the median line occupied by a broadish black stripe, whence five pairs of black stripes pass transversely over the sides of the abdomen; the spaces between these stripes red, hence the lateral surface of the abdomen might be described as ornamented with alternate bands of black and red; the red stripes wider dorsally; the black stripes are narrowest at their point of origin from the median stripe.

Carapace as long as patella + tibia + tarsus of palp, almost half the length of the third leg (measured from the base of the femur), and slightly longer than patella + tibia of first or

* $C f$. de Winton, Ann. \& Mag. Nat. Hist. (7) ii. p. 10 (1898). Ann. \& Mlag. N. Hist. Ser, 7. Vol. xi. 